\title{
The Role of BRICS in International Development Assistance
}

\author{
S. Guo, Yu. Sun, P. Demidov
}

Shuyong Guo - Professor, Dean of the School of International Relations and Public Affairs (SIRPA) of Shanghai International Studies University (SISU); 550 Dalian Road (W), Shanghai 200083, China; E-mail: syguo@shisu.edu.cn

Yulin Sun - LL.M. Candidate at the School of International Relations and Public Affairs (SIRPA) of Shanghai International Studies University (SISU); 1550 Wenxiang Road, Shanghai 201620, China; E-mail: scottsun2716@163.com

Pavel Demidov - LL.M. Candidate at the School of International Relations and Public Affairs (SIRPA) of Shanghai International Studies University (SISU); 1550 Wenxiang Road, Shanghai 201620, China; E-mail: 2req@mail.ru

\begin{abstract}
With their growing economic power and international influence, the BRICS group of Brazil, Russia, India, China and South Africa are paying increasing attention to international development assistance. Although the BRICS countries started later than western developed countries, the speed of their development is staggering and their share in foreign aid is gradually increasing. The BRICS countries continue to innovate forms of assistance and cooperation in their own international development assistance, to strengthen cooperation with recipient countries, and to plan their own foreign aid work through the establishment of relevant institutions and the publication of relevant documents. But, at the same time, the BRICS countries are facing certain challenges in the process of international development assistance. This article examines the historical practice of BRICS' international development assistance, analyzes the role BRICS plays in international development assistance, and considers the future prospects for BRICS' participation.
\end{abstract}

Key words: BRICS; international development assistance; China's efforts

For citation: Guo S., Sun Yu., Demidov P. (2020) The Role of BRICS in International Development Assistance. International Organisations Research Journal, vol. 15, no 2, pp. 92-104 (in English). DOI: 10.17323/199678452020-02-06

\section{International Legitimacy and BRICS International Development Assistance}

In this article, we assume that strive of BRICS to improve its own and overall international legitimacy is one of the keys to explain the growing role of BRICS countries in international development assistance system. We define legitimacy as a belief within a given constituency or other relevant audience that a political institution's exercise of authority is appropriate [Tallberg, Zürn, 2019]. In other words, only legitimate institution can set norms and rules that will be followed by actors. Except for the rulemaking, other main functions of legitimacy include trust-building and agenda-setting. The latter two also serve for the first one, just in order to empower its capacity to develop new norms. 
There are three main dimensions of international legitimacy, which are: procedural, performance and substantive. Procedural legitimacy outlines the importance of right process within the institution, while performance legitimacy focuses on the right way of actions performed by institution. And substantive legitimacy is the significance of the values and substantive agenda of an institution. Between all aforementioned dimensions, we suggest that performance legitimacy applies most effectively for BRICS, as its countries impressive economic performance and, therefore, rapidly increasing "global development assistant" potential, may be seen as the major legitimizing factor for BRICS. This factor is also possible to stimulate the shaping of two other dimensions.

By now, procedural and substantial legitimacy are not that significant, when it comes to BRICS. First of all, BRICS is undoubtedly an international institution, but not in the traditional sense, which suppose that international institution should have a certain structure, with the joint ruling body or mechanism, that implement policy and have a set of procedures. BRICS is more an intergovernmental platform, which coordinate policies between member countries and has a lack of procedural order. Secondly, as it consists of the very different countries, it is harder to set a common agenda on various issues or construct common values, so in the decisionmaking process, consensus is needed.

\section{Summary of the BRICS International Development Assistance Policy}

The growth of the BRICS countries is extremely rapid. The economic development of the BRICS countries is even faster. In 2018, the average GDP growth of the BRICS countries was $5.7 \%$, contributing $43.2 \%$ to the world economic growth. According to purchasing power parity (PPP), the BRICS global GDP share rose from $27.2 \%$ in 2010 to $32.7 \%$ in 2018, greater than the total of G7 added up [NDB, 2019]. After the establishment of the BRICS cooperation mechanism, the scale of economic development of various countries has advanced by leaps and bounds. The role of emerging economies in international development assistance has become increasingly prominent because of the growing national strength of the BRICS countries. According to the Development Assistance Committee, between 2011 and 2014, non-OCED countries increased their foreign aid by $\$ 17.6$ billion from the $\$ 14.1$ billion, accounting for $18.7 \%$ of the 2014 foreign aid quota [Zhao, Jing, Ouyang, 2018].

Although the BRICS countries are based on economic and trade cooperation, since the first summit of the BRICS countries, international development assistance has become a priority for the BRICS countries. This matter ranked fifth $(6.3 \%)$ in the words and documents of the BRICS countries, and fourth in the number of all BRICS obligations [RANEPA CIIR, n. d.]. The table below demonstrates how the BRICS international development agenda and policy have been shaping throughout the years.

This timeline reveals three focal points, which underpin international development policy of BRICS countries. First, it strongly complies with global frameworks, related to international development assistance. For instance, adherence to implementation of UN Sustainable Development Programs, whether Millennium Development Goals (2000-15) or the new Sustainable Development Agreement (2015-30), starting from the very first summit, is the important part of BRICS international assistance agenda and even loom larger within the years.

Second, the "toolkit" of the BRICS international development policy has broadened from simple humanitarian assistance and foreign direct investment (FDI) to more advanced instruments, such as: trade, development financing and etc. In this sense, a decision to establish BRICS New Development Bank (NDB) in 2013 was a crucial achievement. 


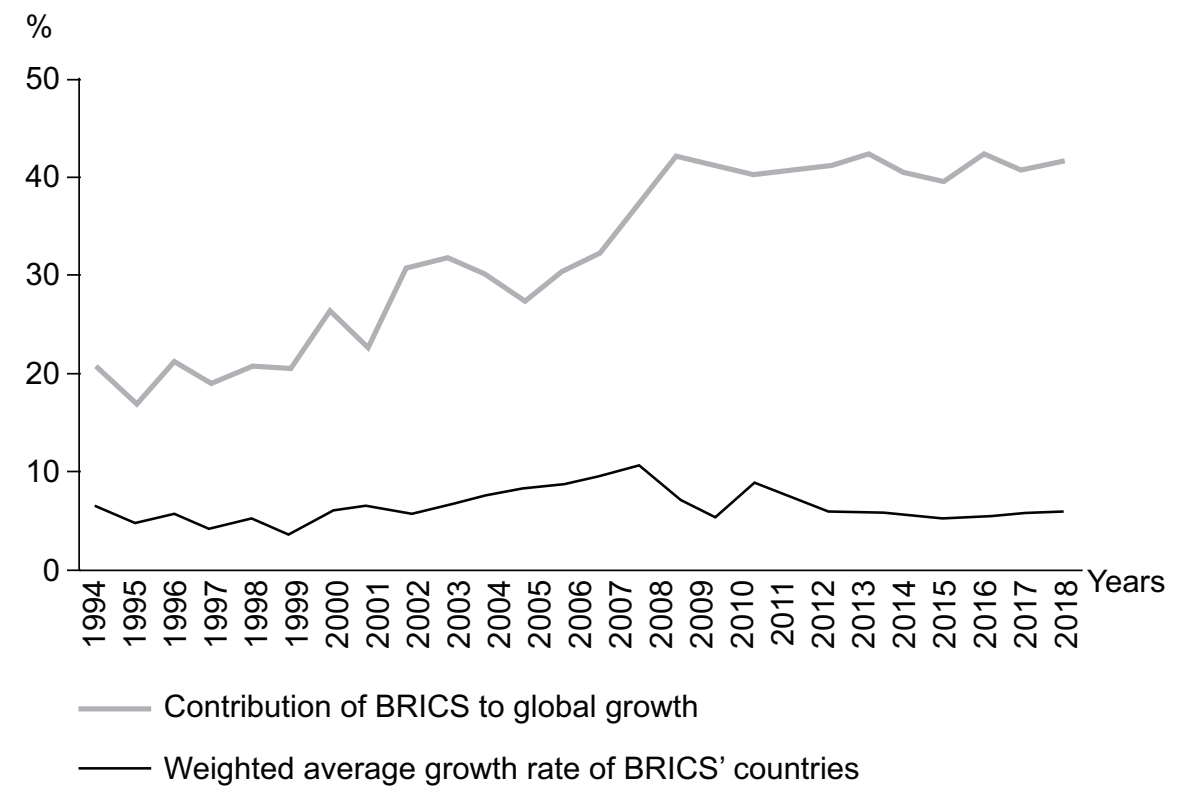

Fig. 2. BRICS Countries and Their Contribution to Global Economic Growth

Source: [NDB, 2019].

Table 1. Contents Related to International Development Assistance in Each BRICS Summit

\begin{tabular}{|c|c|c|c|}
\hline No & Date & Location & Content Related to International Development Assistance \\
\hline 1 & $\begin{array}{l}\text { 16 June } \\
2009\end{array}$ & $\begin{array}{l}\text { Yekaterinburg, } \\
\text { Russia }\end{array}$ & $\begin{array}{l}\text { 1. Emphasize the important role of international trade and foreign direct investment } \\
\text { in economic recovery. } \\
\text { 2. Implement the concept of sustainable development. } \\
\text { 3. Cooperate in key social areas }\end{array}$ \\
\hline 2 & $\begin{array}{l}15 \text { April } \\
2010\end{array}$ & Brasilia, Brazil & $\begin{array}{l}\text { 1. Promote multilateral, comprehensive and sustainable development of the world } \\
\text { economy. } \\
\text { 2. Expand cooperation on global issues to promote world economic recovery and } \\
\text { sustainable growth. } \\
\text { 3. Ensure that developing countries achieve the UN Millennium Development } \\
\text { Goals by } 2015\end{array}$ \\
\hline 3 & $\begin{array}{l}14 \text { April } \\
2011\end{array}$ & Sanya, China & $\begin{array}{l}\text { 1. Conduct global economic governance on the basis of mutual respect and collec- } \\
\text { tive decision-making. } \\
\text { 2. Strengthen cooperation in the fields of economy, finance and trade to ensure the } \\
\text { strong development momentum of the BRICS countries. } \\
\text { 3. Call for the implementation of the reform goals of the International Monetary } \\
\text { Fund proposed by the G20, and increase the voice of emerging economies and } \\
\text { developing countries. } \\
\text { 4. Regulate the commodity trading market }\end{array}$ \\
\hline 4 & $\begin{array}{l}29 \text { March } \\
2012\end{array}$ & New Delhi, India & $\begin{array}{l}\text { 1. Work with all parties to address opportunities and challenges with developed and } \\
\text { developing countries. } \\
\text { 2. Explore the possibility of building New Development Bank and provide develop- } \\
\text { ment finance for BRICS and other developing countries. } \\
\text { 3. Promoting growth and sustainable development is the goal of the BRICS coun- } \\
\text { tries and is essential for economic development, poverty eradication and hunger in } \\
\text { many developing countries }\end{array}$ \\
\hline
\end{tabular}




\begin{tabular}{|c|c|c|c|}
\hline No & Date & Location & Content Related to International Development Assistance \\
\hline 5 & $\begin{array}{l}27 \text { March } \\
2013\end{array}$ & $\begin{array}{l}\text { Durban, South } \\
\text { Africa }\end{array}$ & $\begin{array}{l}\text { 1. Encourage foreign direct investment, knowledge exchange, capacity building, and } \\
\text { African trade integration to support African industrialization. } \\
\text { 2. The BRICS countries can raise funds and agree to establish a New Development } \\
\text { Bank. Ensure that developing countries have access to long-term, stable financing } \\
\text { channels from a variety of sources. } \\
\text { 3. The United Nations should be the center and fulfill its commitments in the out- } \\
\text { come of the international conference }\end{array}$ \\
\hline 6 & $\begin{array}{l}15 \text { July } \\
2014\end{array}$ & Fortaleza, Brazil & $\begin{array}{l}\text { 1. The BRICS countries seek peace, security, development and cooperation, deepen } \\
\text { mutual relations, and realize a new vision of openness, tolerance, cooperation and } \\
\text { mutual benefit. } \\
\text { 2. The BRICS economic growth and socially inclusive policies help stabilize the } \\
\text { world economy, reduce poverty and eliminate inequality. } \\
\text { 3. Information technology can be used as an important tool for achieving sustain- } \\
\text { able social development, promoting the development of renewable energy and } \\
\text { reducing energy consumption. } \\
\text { 4. Support the development of African social and economic development, especially } \\
\text { the infrastructure and industrialization process }\end{array}$ \\
\hline 7 & $\begin{array}{l}9 \text { July } \\
2015\end{array}$ & Ufa, Russia & $\begin{array}{l}\text { 1. Develop relations between BRICS countries and emerging economies, other } \\
\text { developing countries and other international and regional organizations. } \\
\text { 2. Emerging markets and developing countries are important drivers of future social } \\
\text { and economic development. Structural reforms, domestic adjustments, and innova- } \\
\text { tions should be emphasized }\end{array}$ \\
\hline 8 & $\begin{array}{l}16 \text { Octo- } \\
\text { ber } 2016\end{array}$ & Goa, India & $\begin{array}{l}\text { 1. The } 2030 \text { Agenda focuses on poverty eradication and calls on developed countries } \\
\text { to fulfil their commitments of } 0.7 \% \text { of GNI for international development assis- } \\
\text { tance, and to implement the } 2030 \text { Sustainable Development Agreement in line with } \\
\text { national conditions }\end{array}$ \\
\hline 9 & $\begin{array}{l}3 \text { Sep- } \\
\text { tember } \\
2017\end{array}$ & Xiamen, China & $\begin{array}{l}\text { 1. Reaffirming its commitment to the implementation of the UN } 2030 \text { Sustainable } \\
\text { Development Agreement, advocating inclusive development, balanced and coordi- } \\
\text { nated development and cooperation models, supporting UN agreements. } \\
\text { 2. Develop a green and low-carbon economy based on efforts to eradicate poverty } \\
\text { and sustainable development, strengthen cooperation in climate between BRICS } \\
\text { and other emerging countries. } \\
\text { 3. Determined to build a more efficient economic governance structure, increase } \\
\text { the voice and representation of emerging economies and developing countries, and } \\
\text { create a more effective tax system }\end{array}$ \\
\hline 10 & $\begin{array}{l}25 \text { July } \\
2018\end{array}$ & $\begin{array}{l}\text { Johannesburg, } \\
\text { South Africa }\end{array}$ & $\begin{array}{l}\text { 1. Share economic results in a more powerful and inclusive manner and build an } \\
\text { orderly external environment. } \\
\text { 2. Establish a transparent, non-discriminatory and open market order based on } \\
\text { rules, and strengthen the construction of the multilateral trading system. } \\
\text { 3. The BRICS countries should invest heavily in infrastructure on the basis of reci- } \\
\text { procity to support the development of industrialization in Africa }\end{array}$ \\
\hline 11 & $\begin{array}{l}13 \text { No- } \\
\text { vember } \\
2019\end{array}$ & Brasilia, Brazil & $\begin{array}{l}\text { 1. BRICS reiterate the importance of the implementation of the } 2030 \text { Agenda for } \\
\text { Sustainable Development and call for redoubled efforts for its timely implementa- } \\
\text { tion. } \\
\text { 2. BRICS call on developed countries to fully implement their Official Develop- } \\
\text { ment Assistance (ODA) commitments and to provide developing countries with } \\
\text { additional development resources. } \\
\text { 3. BRICS urge developed countries to scale up the provision of financial, tech- } \\
\text { nological and capacity building assistance to developing countries to support mitiga- } \\
\text { tion and adaptation action to a climate change }\end{array}$ \\
\hline
\end{tabular}

Source: Authors.

Third, areas of BRICS international development assistance also evolved. During the first few years of BRICS existence, its countries were mostly emphasizing the importance of international development assistance in fields like food safety, reduction of poverty, education 
and energy. However, starting from 2015 and 2016 summits, BRICS countries international development policy have also focused on issues like social security, innovation, mitigation and adaptation to climate change.

\section{The Role of the BRICS Countries in International Development Assistance}

The model of the BRICS countries broke through the old road of political and military alliances in the past, and came out with a unique new relationship of non-alignment which have broken through the restrictions and constraints of ideology and have embarked on a new path of mutual respect and common progress. In the traditional model, nation states are willing to share power with the international system, but unwilling to share legitimacy, thus bringing challenges to the international system. In the past, it was difficult to conduct win-win cooperation, and the sole winners were able to achieve true multifaceted cooperation and coordination, but the BRICS countries are different. The cooperation and foreign aid of the BRICS countries are based on mutual benefit and mutual benefit. The basic principles are unfolding. The BRICS countries coordinate their actions, strengthen coordination, and jointly promote international development assistance. We point out three main roles of BRICS in IDA system, which are innovator, booster and haven. This section will set out the role that should be played by BRICS countries (and particularly China) in international development.

\section{Innovator to the Patterns of Assistance}

When Chinese President Xi Jinping met with other G20 leaders in Osaka on June 28, noted that BRICS countries should promote the "innovative BRICS" network, adhere to multilateralism, and seek common development and revitalization with other emerging market countries and developing countries [Xinhua wang, 2019]. First of all, the BRICS countries should continue to pay more attention to equal and "green" development. A great way of BRICS to help developing countries in sustainable development is NDB funding. NDB applies sound banking principles to all businesses, ensures adequate compensation and considers risks, provides loans and other business support through guarantees of public or private financial instruments, and can also jointly provide guarantees with international financial institutions and other commercial banks without any politically attached conditions. According to the NDB 2017 annual report, five countries invested a total of $\$ 1400$ billion in 2017. Sustainability and infrastructure assistance are important concerns for NDB's future development, and NDB will provide three fifths of financing for projects that integrate economic, environmental and social standards throughout the lifecycle over the next five years [NDB, 2018]. In the 2018 annual report, NDB is estimated to achieve 35 trillion US dollars in infrastructure investment in 2030, infrastructure investment will reach SDGs with an average growth rate of 26.3\%, and BRICS infrastructure investment is expected to rise from $40.1 \%$ in 2018 to $42.5 \%$ in 2030, compared with $1.1 \%$ of G7 and $1.9 \%$ of growth in other countries [Ibid., 2019].

However, developed countries also attach great importance to sustainable development and institutions led by developed countries, such as the World Bank and the IMF, have long pursued aid policies with additional provisions. In the 1990s, the amount of IMF additional clauses reached its peak, with 73 adjustments to the structure of Thailand, 94 to South Korea, and more than 140 to Indonesia. The World Bank has similar operations. Zhu Jiejin observes that during the 1980s, the World Bank introduced a structural adjustment plan, and in 1999, its Poverty Reduction Strategy Papers (PRSPs) could be considered as a reference for additional 
provisions [Fudan daxue jinzhuan guojia yanjiu zhongxin, 2016]. In the framework of OCED DAC, aid is separated from trade and investment, so that donor countries and recipient countries are in an unequal position. As for China, it has changed its aid methods with political conditions in the past, and truly unconditionally helps difficult countries improve their livelihood. In 2015, Chinese government proposed that China should achieve carbon dioxide emissions by 60-65\% compared with 2005, and non-fossil energy accounts for $20 \%$ of primary energy consumption. The data was $15 \%$ in 2009. The amount of forest savings in the 2015 target is about 4.5 billion cubic meters [Ibid.]. The emerging countries represented by China regard green development and sustainable development as important targets for foreign aid, and achieve green prosperity for themselves and recipient countries.

\section{Booster as a Gradually Rising Star}

The BRICS countries are important participants in international development cooperation, and the proportion of foreign aid at this stage is gradually increasing. Although some BRICS countries have a relatively late process of international development assistance, the momentum of the BRICS countries has maintained a strong momentum. The countries of the South gradually accumulated their own experiences in the development process and began to share the development experience. The foreign aid of the traditional OCED-DAC countries accounted for $0.29 \%$ of the gross national income in 2014, far below the target of $0.7 \%$ of its commitment, and also lower than the share of the early 1990s. Total official development assistance from 2010 began to decline. In 2014, the share bilateral aid for OCED-DAC countries and underdeveloped countries was 16\% lower than in 2013 [Huang, 2018]. At the same time, BRICS countries are pumping up their foreign aid budgets, thus boosting global amount of IDA expenditures. For instance, in 2014, White Paper on China's Foreign Aid issued by China State Council revealed that amount of China's foreign aid in 2010-12 was 89.34 billion yuan $(\$ 12.67$ billion) and now continuously growing throughout the years [Information Office of the State Council of PRC, 2014].

Basically, this boost is the result of the economic globalization and political multipolarization that has brought a precious period of economic development to the BRICS countries. The world's wealth has reversed, and capital flows to developing countries, which is conducive to the accumulation of capital in emerging countries, so that emerging countries represented by the BRICS countries have invested in foreign aid [Li, 2012]. Some countries (such as Russia) successfully transformed from recipient countries to the status of foreign aid countries. According to the Russian Satellite News Agency, in 2016, Russia provided international development assistance to other countries or international organizations amounting to one billion US dollars, this figure is almost 10 times than the number of foreign aid in 2005 which was $\$ 101$ million and it is almost equal to the expenditure of housing public utilities and the media industry [Eluosi weixing tongxunshe, 2017]. In addition, Marina Larionova in Russia: A Re-emerging Donor article notes, that IDA budget of Russia in 2004 was $\$ 100$ million, this figure reached $\$ 785$ million in 2009, nearly eight times that of 2004 [Larionova, Rakhmangulov, Berenson, 2016].

To enhance the implementation and coordination of its IDA policy, China have established National Agency for International Development Cooperation in March 2018. The department reports directly to the State Council and is responsible for formulating China's foreign aid strategy, policies, and coordination of various issues. The projects under the responsibility of the National Agency for International Development Cooperation mainly include a complete set of projects, which includes four ways: provide assistance to the recipient countries with engineering equipment, through the organization of all or part of the production and processing ; provide basic living materials and technical service to the recipient countries; provide technical 
assistance, dispatch experts and skilled workers to help recipient countries to achieve certain goals; conduct human resources development projects, through providing provide recipient countries with various forms of academic degree education, personnel exchanges and senior experts, volunteers and other services. Other important function of this institution is to promote cooperation between related department in various countries. On that institutional level, National Agency for International Development Cooperation held consultations with its Japanese counterpart - Japanese International Development Policy Department in June 2019.

\section{Haven for All Needed Countries}

This concept comes from Melaku Mulualem, director of the training department of the Ethiopian Institute for Diplomatic Relations. The BRICS countries have become one of the most important international organizations in the world and are becoming a safe haven for other developing countries and poor countries with a more positive attitude [Melaku, Li, 2017]. The world today still faces very serious imbalances in development and poverty. Many developing countries still face the impact of globalization and bottlenecks in development. In his speech at the opening ceremony of the BRICS Business Forum on 3 September 2017, Xi Jinping pointed out that the world economy is recovering, emerging countries and developing countries are performing well, and a new round of scientific and technological revolution and industrial transformation are poised for reform and innovation. The trend is moving forward. But on the other hand, 700 million people are suffering from hunger, tens of millions of refugees have been displaced, and countless people and innocent children have been killed. The world economy is in a period of adjustment of sub-health status and weak growth. There are many uncertainties in economic globalization. Therefore, it is necessary to deepen the cooperation in the BRICS, establish itself on its own, promote structural reforms, assume social responsibilities, and safeguard world peace [Xinhua wang, 2017].

The BRICS countries are promoting the balanced development of emerging countries and underdeveloped countries through the "BRICS+" cooperation model and become a safe haven for poor countries. Aid experience of western countries have provided direction for BRICS. A large amount of aid funds from OCED countries have flowed to the field of social development, such as agriculture and forestry, and the lack of attention to the infrastructure sector has also provided lessons for the BRICS countries [Fudan guoji guanxi pinglun, 2016]. BRICS have learnt great experience, focusing on the comprehensive development especially in infrastructure, at the same time, strengthened cooperation in humanitarian assistance, making humanitarian assistance activities one of the most important parts of the BRICS agenda. In 2011-2013, the number of external humanitarian assistance from BRICS countries was $6 \%$. ( $\$ 0.8$ billion) increased to $11 \%$ ( $\$ 1.4$ billion). The BRICS countries attach importance to the eradication of poverty and hunger, especially in the backward areas of Asia and Africa [Degterev, 2014]. In addition, the BRICS countries are implementing projects in the fields of health, education and technological development in Asia and Africa.

Whilst providing a great amount of aid for Africa, the BRICS countries are also adopting an inclusive attitude and achieving international development assistance to Africa on the basis of respecting the path of equality among African countries in their own way of development rather than coercion. According to statistics, in 2012, the total trade volume of BRICS countries to Africa reached 340 billion US dollars, accounting for $27 \%$ of total African trade. The share of Africa's trade has risen nearly tenfold from a decade ago. In comparison, the European Union's trade in Africa during this year was 34\%. At this stage, although developed countries still occupy a very large proportion of trade with Africa, it can be seen from Figure 2 that the amount of official development assistance in developed countries is declining, while the contribution of 
emerging countries represented by BRICS countries It is gradually rising. In 2011, among the top 20 African trading partners, the trade volume of developed economies to Africa was 390.2 billion euros, and that of emerging countries represented by BRICS countries was 277.3 billion euros [Fudan guoji guanxi pinglun, 2016].

DAC Official Development Assistance

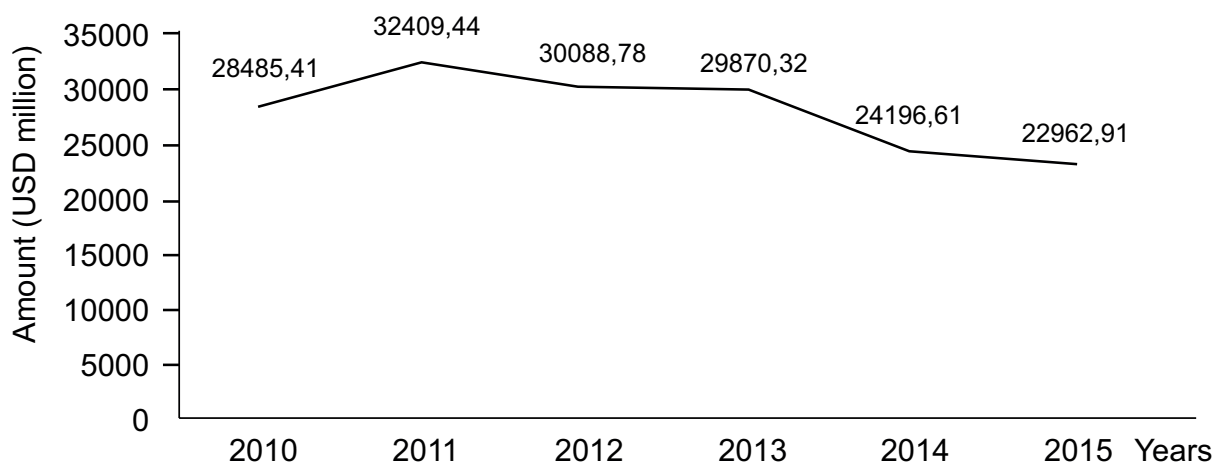

Non-Dac Official Development Assistance

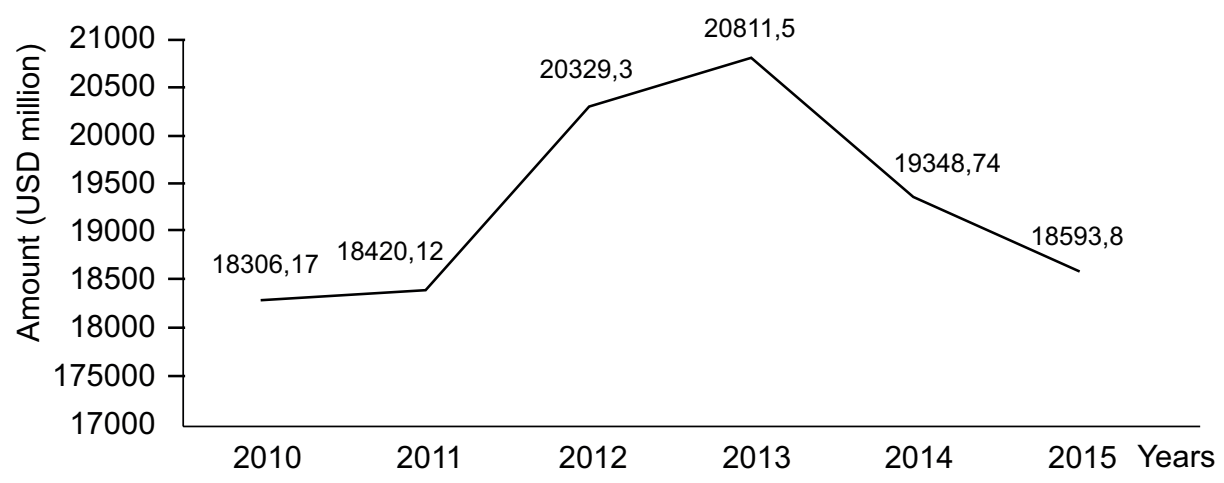

Fig. 2. Trends in DAC Countries' Aid to Non-DAC Countries Versus Africa

Source: [Africa Economic Outlook, n. d.; data from authors].

\section{The Future of BRICS Participation}

\section{Prospects for the Future of BRICS Foreign Aid Work}

Leading the international Development Assistance. The BRICS international development assistance started relatively late compared to developed countries, and BRICS countries such as Russia, China, and India were also recipients. However, the current state of foreign aid in the BRICS countries is gratifying, and has created a model of assistance, which is different from traditional Western powers and focusing on trade, peace and sustainable development. In 2010, when Western countries reached a peak in foreign aid, foreign aid fell by $3 \%$ in 2011. In 2011, OECD countries invested $\$ 133.5$ billion in foreign aid, and its amount still did not reach the UN target of $0.7 \%$. 16 of 23 OECD countries have reduced their foreign aid budgets [Huang, 2013]. However, the emerging economies represented by the BRICS countries not only seize 
the opportunity of the world economic development, but also vigorously develop their own economic strength.

Taking China as an example, China's Reform and Opening-up policy have succeeded. Most of the people have got rid of poverty and achieved a well-off society. China also actively participate in the process of international development assistance and become an important force for foreign aid. The BRICS countries actively respond to the UN's Millennium Development Plan and the 2030 Sustainability Agreement, bringing development opportunities and aid funding to poor areas. In the future, the BRICS will maintain an open, inclusive and mutually beneficial approach to assistance, improving the infrastructure and commodity markets of the recipient countries and recipient countries, providing foreign aid on the basis of developing their own economies. As an important part of diplomatic work, the proportion of international development assistance has shown an overall upward trend, and it has continued to move closer to the aid share of developed countries.

Improving of the Assistance System by Cooperating With UN. Due to the fierce competition between developed countries and emerging economies in international development assistance field, both sides hope to expand their influence through foreign aid and receive the support of the international community. Therefore, they have provided decent assistance conditions for recipient countries. Recipient countries have certain principle rights, so the choice between developed countries and BRICS will intensify competition between the two sides, which resulting in the fragmentation of the overall aid system, development of national foreign aid programs and the participation of the countries in international development assistance, and it is also likely to cause waste of aid resources. In the future process of foreign aid development, BRICS countries won't only cooperate between each other on internal affairs, but also increase the joint efforts of BRICS countries in foreign aid field. At the same time, they will work together with other emerging countries to contribute to poverty eradication, sustainable development.

Both developed and emerging countries are committed to providing foreign aid in accordance with the UN 2030 Sustainable Development Agreement and to abide by their commitment to the people of the world. As a representative of non-governmental organizations, the United Nations is playing an increasingly important role in international development assistance. The United Nations launched the 2030 Sustainability Agreement in 2015, which stated that sustainable development should be based on inclusive attitudes, equality and mutual benefit, with a focus on poverty eradication efforts to address rising economic inequalities and social deprivation [Nan nan hezuo jinrong zhongxin, 2017]. BRICS emphasized support for the United Nations, including its high-level political forum on sustainable development, advocating fair/ comprehensive/inclusive development, and an equitable and coordinated economic development model, and urged developed countries to complete development assistance commitments on time and provide more resources for developing countries.

Promote Investment in the "Aid for Trade" System. The inclusion of trade in the process of international development assistance is the innovative act made by BRICS. In the case of non-trade aid, the United Nations Trade Development Organization statistics show that in 2010, amount of foreign investment in Africa was \$308.74 billion, for developed countries the proportion was $77 \%$, and $13.8 \%$ for BRICS countries. That period was an initial stage in international development assistance for emerging economies, represented by BRICS countries. Since 2012, the volume of merger and acquisition conducted by emerging economies have also far surpassed that volume of developed countries. After being affected by the financial crisis, western countries have shown negative values for non-mergers. Although the BRICS countries have also received certain fluctuations, they are still at the overall rising stage. In terms 
of greenfield investment in Africa, the proportion of non-greenfield investment in developing countries increased from $42.5 \%$ to $63 \%$ in 2011, while that in developed countries decreased from $54.6 \%$ to $36.9 \%$ [Fudan guoji guanxi pinglun, 2016]. In the future, the BRICS countries should continue to expand their investment fields, continue to exert their strengths in construction, electronics, warehousing and communication, and at the same time innovate investment areas, attach importance to sustainable energy development and construction, and continue to promote Aid for Trade system.

\section{Difficulties and Challenges}

Insufficient Infrastructure and Funding. BRICS countries still do not match the speed of economic development and the scale of economic development. Infrastructure is an important tool to support a country's economic construction and people's happiness index, and is also an important basis for a country's foreign aid. The BRICS countries face the embarrassing situation of insufficient infrastructure construction and dragging down economic competitiveness. According to the Global Competitiveness Report 2014-15, China, Russia, South Africa, Brazil, and India rank 86th, 74th, 59th, 120th, and 90th, and these countries rank 28th 53th, 56th, 57 th, 71 th in competitiveness. BRICS countries generally face a situation of strong competitiveness and backward infrastructure. In order to cope with this situation, the BRICS countries have also begun to build infrastructure.

Russia introduced the Russian Railway Transport Development Strategy 2030 and plans to build a railway with a total length of 20,000 kilometers by 2030, of which 5,000 kilometers will be a high-speed railway, and the planned investment will reach 14 trillion rubles [Gao et al., 2015]. China vigorously promotes the construction of clean energy and invested 291 million dollars to build a clean energy project in Guangdong, and promote the development of domestic infrastructure, such as the Luoyang subway project. India will also invest about \$1 trillion in infrastructure to build infrastructure projects including electricity, roads, ports, and communications. The Brazilian government also issued a corresponding document in 2012, in which the Brazilian government plans to invest $\$ 65.6$ billion in the cost of building high-speed kilometers and railways over the next 20 years. In 2015, the Brazilian government enacted a second phase of transportation infrastructure investment plans, with an estimated investment of $\$ 64$ billion. South Africa will aim to break through the bottleneck in infrastructure construction, investing $\$ 74$ billion in infrastructure construction and will continue to expand the scale of infrastructure construction [Ibid.].

Lack of Aid Documents and Regulations. Unlike the general international organizations, the BRICS countries do not have a programmatic document as a guide in the economic and political development of the five countries because of their unique mode of cooperation and non-alignment and the development of inclusiveness. These assistance norms are necessary conditions to ensure agents formulate rules and ensure rules can be observed. Only normative constraints can ensure that people who obey the rules have a certain degree of consciousness to abide by the relevant rules or not interfere with others' obedience. This is a manifestation of the right of international governance to rule. Although China has promulgated the China Foreign Aid (2014) White Paper, and Russia has issued its foreign aid concept, but fundamentally, these documents are not a programmatic and can be coordinated.

The documents of the BRICS countries in achieving international development assistance cooperation do not have legal effect. One manifestation of the lack of programmatic documents is that the BRICS countries will encounter a strange circle in foreign aid, that is, the recipient countries need assistance needs, and the aiding countries will analyze, assess and determine 
the final aid plan. This is "demand-driven" [Zhao, Ying, Ouyang, 2018]. In the absence of assistance applications, aid donors rarely voluntarily propose foreign aid, which is difficult for countries to incorporate foreign development assistance into their own development plans. China actively provides medical assistance to 69 countries in Asia, Africa, Latin America and the Caribbean and Oceania [Renmin wang, 2015].

\section{Conclusion}

At a time when international development assistance is highly valued by the global community, BRICS became a major emerging force in this field. Since the establishment of this format, its role within IDA system have grown substantially, not only in terms of quantity, but also in terms of quality. First of these qualitative changes is the shift of the identity, most of the BRICS countries used to be recipients of foreign aid during certain periods of their history, but now actively dealing with the status of non-traditional donors. At the same time, BRICS nations (except for Russia) still position themselves as the developing countries and therefore act as a "haven" for other low-income states, attach great importance to the economic development of poverty-stricken areas and setting new standards for inclusive and equal assistance. Second, foreign aid strategy of BRICS has evolved from extensive usage of humanitarian assistance to more complex projects that involve flows of money, science and technology, education, knowledge sharing, trade and other measures. These new instruments, along with the new issues (like climate change), that shape modern IDA agenda, allow BRICS to take roles of "innovator" and "booster" of the international development assistance.

However, it should also be noted, that there are still certain problems with the current BRICS participation in international development cooperation, such as insufficient infrastructure construction, funding gap, and lack of assistance documents and regulations. But despite these challenges, BRICS also have some favorable conditions, both internal and external. At first, BRICS countries are improving their cooperation model, and join its forces to build a "BRICS+" platform. At second, support from the UN, World Bank and other major international institutions. In the future, the participation of BRICS in international development assistance has bright prospects. In the future, the participation of BRICS in international development assistance has bright prospects. Five countries have embarked on a new road of developing their own strength, grasping the opportunities of economic globalization and will take the lead in improving international development assistance system within the framework of UN 2030 Sustainable Development Agreement. In providing joint and its own IDA policy, China will rely on the National Agency for International Development Cooperation, which have to coordinate with other departments to work out national foreign aid programs. Finally, development assistance is the really important tool to shape an international legitimacy, which allows to resist multilateral competition pressure and unilateral action.

\section{References}

African Economic Outlook. (n. d.) Statistics. Available at: https://www.africaneconomicoutlook.org/statistics/ (accessed 19 April 2020).

Degterev D. (2014) Rossiiskaya politika v sfere SMR - konturi partnyorstva so stranami BRICS [Russia IDA Policy - Contours of BRICS Partnership]. Journal of Peoples Friendship University of Russia, no 1, pp. 5-12 (in Russian). Available at: https://cyberleninka.ru/article/n/rossiyskaya-politika-v-sfere-sodeystviya-mezhdunarodnomu-razvitiyu-kontury-partnerstva-so-stranami-briks/viewer (accessed 19 April 2020). 
Eluosi weixing tongxunshe. (2017) Eluosi 2016 nian duiwai yuanzhu guimo yuewei 12 nian qian de 10 bei [Russia's Foreign Aid in 2016 Was About 10 Times the Size of 12 Years Ago]. 10 October (in Chinese). Available at: http://sputniknews.cn/russia/201710101023775741/ (accessed 19 April 2020).

Fudan daxue jinzhuan guojia yanjiu zhongxin. (2016) Guoji zhili yu jinzhuan guojia de jiejue fang'an [International Governance and BRICS Solutions]. Shanghai: Shanghai renmin chubanshe (in Chinese).

Zheng Y., Li X. (ed.). (2016) Guoji fazhan hezuo xin fangxiang [New Directions for International Development Cooperation]. Shanghai: Shanghai renmin chubanshe (in Chinese).

Gao X. et al. (2015) Jinzhuan guojia fazhan baogao 2015 [BRICS Development Report 2015]. Beijing: Zhongguo shehui kexue chubanshe (in Chinese).

Huang C. (2013) Quanqiu yuanzhu zhili de jizhi yu moshi [The Mechanism and Model of Global Aid Governance]. Alabo shijie yanjiu, no 3, pp. 29-39 (in Chinese). Available at: https://kns.cnki.net/KCMS/detail/ detail.aspx dbcode $=$ CJFQ \&dbname $=$ CJFD2013\&filename $=$ ALBJ201303005\&v=MTY4MThSOGVYMUx1 eFITN0RoMVQzcVRyV00xRnJDVVI3cWZZZVpxRkN2bVdyL05KQ0hKWkxHNEg5TE1ySTIGWVk= (accessed 19 April 2020).

Huang C. (2018) Quanqiu fazhan zhili zhuanxing yu Zhongguo de zhanlüe xuanze [Global Development Governance Transformation and China's Strategic Choice]. Guoji zhanwang, vol. 10, no 3, pp. 29-49, pp. 153-154 (in Chinese). Available at: https://www.cnki.net/kcms/doi/10.13851/j.cnki.gjzw.201803003.html (accessed 19 April 2020).

Information Office of the State Council of the People's Republic of China. (2014) China's Foreign Aid. Available at: http://www.scio.gov.cn/zxbd/nd/2011/document/896900/896900.htm (accessed 19 April 2020).

Larionova M., Rakhmangulov M., Berenson M.P. (2016) Russia: A Re-Emerging Donor. The BRICS in International Development (J.Gu, A. Shankland, A. Chenoy (eds)). London: Palgrave Macmillan.

Li D. (2012) Jinzhuan guojia - shijie de xiwang [BRICS Countries - The Hope of the World]. Beijing: Beijing gongye daxue chubanshe (in Chinese).

Melaku M., Li J. (2017) Feizhou de jinzhuan jiyu [BRICS Opportunities in Africa]. Zhongguo touzi, no 18, pp. 28-33 (in Chinese). Available at: https://kns.cnki.net/KCMS/detail/detail.aspx?dbcode=CJFQ\&dbnam$\mathrm{e}=$ CJFDLAST2017\&filename $=$ ZGTZ201718011\&v=MDA4MzJGQ2psVTc3T1B5cmZkTEc0SDliTnA0OUV aWVI4ZVgxTHV4WVM3RGgxVDNxVHJXTTFGckNVUjdxZlllWnE= (accessed 19 April 2020).

Nan nan hezuo jinrong zhongxin. (2017) Maixiang 2030: nan nan hezuo zai quanqiu fazhan tixi zhong de juese bianhua [Toward 2030: The Role of South-South Cooperation in the Global Development System]. Beijing: Zhongguo shehui kexue chubanshe (in Chinese).

New Development Bank (NDB). (2018) NDB Annual Report 2017: Developing Solutions for a Sustainable Future. Available at: https://www.ndb.int/wp-content/uploads/2018/07/NDB_AR2017.pdf (accessed 19 April 2020).

New Development Bank (NDB). (2019) NDB Annual Report 2018: Investing for Impact. Available at: https:// www.ndb.int/wp-content/uploads/2019/07/NDB_AR2018.pdf (accessed 19 April 2020).

RANEPA CIIR. (n. d.) BRICS sodejstvie razvitiyu [BRICS in Development Assistance]. Available at: https:// www.ranepa.ru/ciir/sfery-issledovanij/sodejstvie-razvitiyu/osnovnye-organizatsii-v-sfere-sodejstviya-razvitiyu/briks/ (in Russian) (accessed 19 April 2020).

Renmin wang. (2015) Zhongguo 60 duo nian xiang 166 ge guojia he guoji zuzhi tigong jin 4000 yi yuan yuanzhu [In More Than 60 Years China Has Provided Nearly 400 Billion Yuan in Aid to 166 Countries and International Organizations]. 16 October. (in Chinese) Available at: http://politics.people.com.cn/n/2015/1016/c100127706166.html (accessed 19 April 2020).

Tallberg J., Zürn M. (2019) The Legitimacy and Legitimation of International Organizations: Introduction and Framework. Review of International Organizations, vol. 14, pp. 581-606. Available at: https://doi.org/10.1007/ s11558-018-9330-7.

Xinhua wang. (2017) Xi Jinping zai jinzhuan guojia gongshang luntan kaimushi shang de jianghua [The Speech of Xi Jinping During the Opening Ceremony of the BRICS Business Forum]. 3 September. Available at: http://www. xinhuanet.com//politics/2017-09/03/c_1121596338.htm (accessed 19 April 2020) (in Chinese). 
Xinhua wang. (2019) Xi Jinping chuxi ershiguo jituan lingdaoren dishisici fenghui bing fabiao zhongyao jianghua [Xi Jinping Visits the 14th Meeting of G20 Leaders and Delivers an Important Speech]. Available at: http://www. xinhuanet.com/world/2019-06/28/c_1124684861.htm (accessed 19 April 2020) (in Chinese).

Zhao J., Jing Y., Ouyang Z. (2018) Xinxing yuanziegou yanjiu huguo duiwai fazhan yuanzhu de zhili jiegou yanjiu: jiyu bufen jinzhuan guojia de bijiao fenxi [Research on the Governance Structure of New Development Assistance Countries' Foreign Development Assistance: Based on Comparative Analysis of Some BRICS Countries]. Zhongguo xingzheng guanli, no 2, pp. 130-136 (in Chinese). Available at: https://kns.cnki.net/ KCMS/detail/detail.aspx?dbcode $=$ CJFQ \&dbname $=$ CJFDLAST2018\&filename $=$ ZXGL201802025\&v $=$ MjI wNzVoVzczT1B6WE1Zckc0SDluTXJZOUhZWVI4ZVgxTHV4WVM3RGgxVDNxVHJXTTFGckNVUjdxZll IWnFGQ24= (accessed 19 April 2020). 